\title{
Knowledge, attitudes and misconceptions of primary care physicians regarding fever in children: a cross sectional study
}

Figen Demir ${ }^{1^{*}}$ and Ozgur Sekreter ${ }^{2}$

\begin{abstract}
Background: Fever is an extremely common sign in paediatric patients and the most common cause for a child to be taken to the doctor. The literature indicates that physicians and parents have too many misconceptions and conflicting results about fever management. In this study we aim to identify knowledge, attitudes and misconceptions of primary care physicians regarding fever in children.
\end{abstract}

Methods: This cross-sectional study was conducted in April-May 2010 involving primary care physicians $(n=80)$. The physicians were surveyed using a self-administered questionnaire. Descriptive statistics were used.

Results: In our study only $10 \%$ of the physicians knew that a body temperature of above $37.2^{\circ} \mathrm{C}$ according to an auxiliary measurement is defined as fever. Only $26.2 \%$ of the physicians took into consideration signs and symptoms other than fever to prescribe antipyretics. $85 \%$ of the physicians prescribed antipyretics to control fever or prevent complications of fever especially febrile seizures. Most of the physicians (76.3\%) in this study reported that the height of fever may be used as an indicator for severe bacterial infection. A great majority of physicians (91.3\%) stated that they advised parents to alternate the use of ibuprofen and paracetamol.

Conclusions: There were misconceptions about the management and complications of fever. There is a perceived need to improve the recognition, assessment, and management of fever with regards to underlying illnesses in children.

Keywords: Children, Fever, Physician attitudes

\section{Background}

Fever is an extremely common sign in paediatric patients and the most common cause for a child to be taken to the doctor [1]. Fever in children less than five years of age can be a diagnostic challenge for primary care physicians and even for paediatricians, because it is often difficult to identify the cause. In most cases, fever is due to a self-limiting viral infection including acute upper respiratory infection, however, it may also be the presenting feature of serious bacterial infections such as meningitis or pneumonia, fortunately this represents a minority of cases [2]. In these cases fever is considered a beneficial part of the immune response [3,4]. More

\footnotetext{
* Correspondence: figen.demir@acibadem.edu.tr

'Department of Public Health, Acıbadem University School of Medicine, Gülsuyu Mah. Fevzi Çakmak Cad. Divan Sok. No: 1, Maltepe/ISTANBUL 34848, Turkey

Full list of author information is available at the end of the article
}

recent studies have shown that a significant number of children (around 48\%) show no obvious cause of fever despite careful assessment [5]. Paediatricians recommend the natural way and/or prescribe medication to lower the fever. This paediatric policy is not intended to quicken recovery but to ensure the comfort of the child [6]. Actually there are only a few reasons for using the antipyretic therapy mentioned above [3,4]. For more than three decades the beneficial effects of mild fever have been known [7]. In 1980 Schmitt discussed parental misconceptions and fear of fever and defined this fear as fever phobia [7]. Physicians contribute to this fever phobia by their incomplete and insensible messages to parents. May and Baucher published a study conforming to the problem of misinformation about fever. This study set forth that instructions given to parents about fever are often inaccurate and physicians also have some

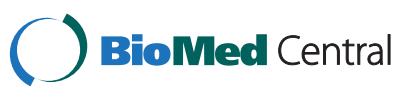


misconceptions about fever and its complications. Most of the primary care physicians and even paediatricians believed that fever is dangerous and cause brain damage and febrile convulsions [8].

Although fever has beneficial effects and is good for the immune response, it seems that the negative perceptions of fever, like fears of febrile seizures and fever phobia, remain unchanged. Physicians continue to reduce low grade fever without other symptoms and recommend various kinds of antipyretics to feverish children despite initial treatment $[9,10]$. In brief, these misconceptions cause unnecessarily aggressive and inappropriate management of feverish children [7,11-16].

Nevertheless there are also conflicting results about fever management in the literature and these conflicts may also contribute to physicians' misconceptions.

In this study we aim to identify knowledge, attitudes and misconceptions of primary care physicians regarding fever in children.

\section{Methods}

This cross-sectional study was conducted in April-May 2010 involving all primary care physicians working in a province with a population of 600000 .

During vaccine distribution, researchers went to each primary health care centre to inform physicians about the study. Data was collected after the purpose of the study was explained to the participants and they were informed that their participation was voluntary. Approval for the study was obtained from the Turkish Ministry of Health Local Health Authority of the province in which the research was carried out. The study participants were all primary care physicians who worked in primary health care facilities during the period of study. A sample was not selected, but there were attempts to contact the whole population. Physicians who were on holiday or ill at home during the period of study were excluded from the study. Two of 82 physicians refused participation (the participation rate was 97.4\%). Physicians were surveyed using a self-administered questionnaire. It was comprised primarily of closed ended questions about basic demographic characteristics, working conditions, number of working years and setting of practice, knowledge, attitude and management of fever in children.

The data was analyzed using the SPSS 16.0 program and descriptive statistics were used.

\section{Results}

The study included 80 physicians (participation rate $97.4 \%$ ) with a mean age of $36.5 \pm 8.3$ and the male-female ratio was 1 . The socio-demographic characteristics of the participants are presented in Table 1.
Table 1 Demographical Characteristics of Physicians

\begin{tabular}{ll}
\hline Characteristics & Descriptive statistics \\
\hline Female, N (\%) & $40(\% 50)$ \\
Age (mean \pm sd) & $36.5 \pm 8.3$ \\
Marital status & \\
Married $\mathbf{n}(\%)$ & $60(\% 75)$ \\
Single $\mathbf{n}(\%)$ & $20(\% 25)$ \\
Participant with children & \\
Yes $\mathbf{n}(\%)$ & $52(\% 65)$ \\
No $\mathbf{n}(\%)$ & $28(35 \%)$ \\
Duration of working (mean \pm sd) & $10.8 \pm 7.8$ \\
Number of patients per week (mean $\pm \mathbf{~ s d ) ~}$ & $357.4 \pm 188.1$ \\
\hline N number, sd standard deviation. &
\end{tabular}

There was an internet connection in all of the health care centres. Only a few physicians (7.5\%) undertaken training regarding fever after their postgraduate studies and $27.5 \%$ of the physicians indicated that they had read an article associated with fever in the last 6 months.

Most of the physicians (83.8\%) recommended an auxiliary measurement of fever to the parents of the febrile child and $10 \%$ of them indicated that a body temperature of above $37.2^{\circ} \mathrm{C}$, according to an auxiliary measurement, was treated as fever. The body temperature treated as fever by physicians according to an auxiliary measurement varied between $36.5^{\circ} \mathrm{C}$ and $39^{\circ} \mathrm{C}$. About two thirds of physicians $(73.8 \%)$ reported that they recommended an antipyretic agent to every child under the age of 5 with fever. Only $26.2 \%$ of physicians took into consideration signs and symptoms other than fever (malaise, irritability, prolonged crying, signs of infection) to prescribe the antipyretic. Nevertheless only $15 \%$ of physicians indicated that they prescribed antipyretics to ensure the child's comfort and remove irritability. The rest of the physicians prescribed antipyretics to control fever and prevent complications of fever, especially febrile seizures.

Some of the statements regarding the management and complications of fever, in agreement with these statements of physicians, are shown in Table 2.

Most of the physicians (90\%) indicated that febrile convulsions can cause brain damage. More than half (65.0\%) of the physicians said that fever is harmful for the child and $70.7 \%$ of them reported that a body temperature of above $38^{\circ} \mathrm{C}$ must definitely be treated, whatever the underlying pathology . Many (76\%) believed that the main reason for antipyretic usage is to prevent febrile convulsion and $87.5 \%$ indicated that physical methods (bathing) should be recommended to reduce fever. Other physical methods like cold application and rubbing the body with alcohol were also recommended by the majority of the physicians (Table 2). Most of the physicians (84\%) believed there is a positive correlation 
Table 2 Distribution of physicians' agreement to some statements regarding fever management and complications in febrile children under the age of 5

\begin{tabular}{|c|c|c|}
\hline Statements & Number & Percent \\
\hline Fever is dangerous for a child & 52 & 65.0 \\
\hline A fever lower than $38^{\circ} \mathrm{C}$ should definitely be treated even when there are no other signs and symptoms & 14 & 17.5 \\
\hline A body temperature of above $38^{\circ} \mathrm{C}$ must definitely be treated whatever the underlying pathology & 56 & 70.7 \\
\hline Prevention of febrile convulsion is the main reason for antipyretic usage & 60 & 75.0 \\
\hline Brain damage, seizures and death are complications of fever & 62 & 77.5 \\
\hline Medical treatment must definitely be used in reducing fever & 29 & 36.3 \\
\hline Physical methods like baths should be recommended to reduce fever & 70 & 87.5 \\
\hline Cold application should be recommended to reduce fever & 56 & 70.0 \\
\hline Rubbing the body with alcohol must be recommended to reduce fever & 18 & 22.5 \\
\hline Sleeping febrile children must not be disturbed & 8 & 10.0 \\
\hline Fever is a risk factor for brain damage & 68 & 85.0 \\
\hline The risk of febrile convulsion increases when the fever increases & 68 & 85.0 \\
\hline Brain damage may occur after febrile convulsion & 72 & 90.0 \\
\hline Teething is a reason for fever & 57 & 71.3 \\
\hline $\begin{array}{l}\text { Paracetamol or ibuprofen usage should be recommended to prevent fever and local reactions associated with } \\
\text { childhood vaccination }\end{array}$ & 65 & 81.3 \\
\hline High fever may be used as an indicator of severe bacterial infection & 61 & 76.3 \\
\hline Paracetamol and ibuprofen are the only antipyretic drugs recommended for use in children & 53 & 66.3 \\
\hline Ibuprofen and paracetamol can be used alternatively & 73 & 91.3 \\
\hline Acetylsalicylic acid should not be used in a febrile child & 73 & 91.3 \\
\hline Oral administration of paracetamol is preferable to rectal administration in children & 62 & 77.5 \\
\hline
\end{tabular}

between the height of fever and the incidence of febrile convulsion. According to $82.7 \%$ of the physicians, teething is a cause of fever. Inappropriate beliefs about antipyretics were confirmed by the $78.7 \%$ who agreed that paracetamol and ibuprofen can be used alternatively. More than half (68\%) of the physicians agreed that only paracetamol and ibuprofen should be used as antipyretics in children.

\section{Discussion}

The first major finding of this research is a variation in the definition of fever. Fever is defined as a body temperature greater than $37.2^{\circ} \mathrm{C}$ according to an auxiliary measurement by primary care physicians [10]. In our study only $10 \%$ of physicians knew that a body temperature of above $37.2^{\circ} \mathrm{C}$ according to an auxiliary measurement is defined as fever. Body temperature treated by physicians as fever varied between $36.5^{\circ} \mathrm{C}$ and $39.0^{\circ} \mathrm{C}$. This range is too great. Definitions of high fever by physicians also varied significantly in other studies $[17,18]$. In our study most of the physicians $(83.8 \%)$ recommended an auxiliary measurement of fever to the families. There are conflicting results as regards this subject. Some authors consider tympanic measurement the best method for non-invasive measurement [19-21], some authors recommend an auxiliary measurement because it is easy to perform and generally well tolerated. However, it is not very sensitive [22]. According to the Italian paediatric society guidelines, auxiliary measurements using a digital thermometer is recommended in all children for measurements taken at home [23]. Physical temperature reducing methods such as cold application and rubbing the body with alcohol were recommended in our study. But in fever management guidelines and studies of the use of these methods to reduce fever, physical methods are not recommended as their usage may be associated with adverse effects and a paradoxical increase in fever [23-26]. Severe complications such as hypoglycaemia, coma or even death may be seen in a febrile child due to rubbing with alcohol [24,25].

In the present study about two thirds of physicians (73.8\%) recommended an antipyretic agent to every child under the age of 5 with fever, whatever the signs and symptoms. Only $26.2 \%$ of physicians took into consideration signs and symptoms other than fever (malaise, irritability, signs of infection) to prescribe antipyretic. In fact according to guidelines, antipyretics should not be used routinely in management of a febrile child [20,21]. Use of antipyretics in children is recommended in case 
of prolonged crying, irritability, reduced activity and sleeplessness [27].

Only $15 \%$ of physicians indicated that they prescribed antipyretics to ensure a child's comfort and remove irritability, except for reducing fever. The rest of the physicians prescribed antipyretics to control fever, and prevent complications of fever especially febrile seizures. International literature confirms that fever phobia is common among parents and health care workers. Misconceptions about complications of fever especially febrile convulsions often push health care workers to over treat fever and this reinforces the phobia among parents $[9,28]$. The result of the present study confirmed these findings. According to our study there have been few changes in physicians' knowledge and attitudes over the past years. Fever phobia continues. More than half of the physicians (65\%) considered fever to be dangerous for a child. It is known that antipyretic treatment has not been effective in the prevention of simple febrile seizures [29-32]. In our study $75 \%$ of physicians reported that the main reason for antipyretic usage was to prevent febrile seizure. In another study which was conducted in Saudi Arabia, this ratio was 70\%, i.e. similar to that of our study [9]. In Israel $8.7 \%$ of 1000 primary care physicians, paediatricians, general practitioners and family specialists considered avoidance of febrile seizure to be the main reason of antipyretic usage [33]. Due to the participation of specialists, the misconception was less common in this population.

Although there have been no evidence that fever causes brain damage unless it reaches above $41^{\circ} \mathrm{C}$, it is still a common misconception among physicians $[34,35]$. Fortunately, fever seen in children rarely reaches this high temperature. The most common side effects of fever are benign and include minimal dehydration, increased sleepiness, and discomfort [36]. In our study $85 \%$ of physicians stated that fever was a risk factor for brain damage. There are also other articles that surveyed physicians' opinions and behaviours with regards to fever, which confirm that fever is seen as a risk factor for brain damage. Unfortunately health care workers and parents believe that brain damage is a consequence of fever $[34,35]$.

Febrile seizure is a rare complication of fever, occurs in $2-4 \%$ of febrile children and most are self-limited without any long-term sequelae [36-41]. Despite there being no evidence to suggest that brain damage may occur after febrile convulsion [42-44], in our study $90 \%$ of the physicians believed that brain damage might occur after febrile convulsion.

This misconception is common not only in our study population but also among other physicians working in primary health care, hospitals and emergency rooms $[8,9,45]$.

In our study $85 \%$ of physicians agreed that the higher the temperature, the higher the likelihood of a febrile seizure. There are conflicting results about the association between the risk of febrile convulsion and the height of fever. Some authors think that height of body temperature plays a more important role in the pathogenesis of a febrile seizure than the rapidity of the rise in temperature [46-48], but some disagree with this observation [49]. It is said that the most significant risk factor for the development of a first febrile seizure is the height of the temperature; the higher the temperature, the higher the likelihood of a febrile seizure [50]. Nevertheless according to other authors; febrile seizures may be more likely to occur with rapid rises in temperature [51], at the onset of febrile illnesses or with a rapid decrease in temperature (alcohol sponging). In a study one third of all children who have febrile seizures will have a second episode despite attempts to prevent fever with antipyretics [52]. In a randomised controlled trial, 157 children who enrolled after their first febrile convulsion were followed for two years. In this study there was no evidence found that antipyretic treatment reduced the risk of febrile convulsions [53]. The last two observations supported the argument that height of fever may not be related to febrile seizures.

Most of the physicians (76.3\%) in this study reported that height of fever can be used as an indicator for severe bacterial infection. Some studies have found a causal relationship between the height of fever and the severity of the underlying pathology e.g. bacterial infection; others have not [54-57]. According to evidence obtained from observational studies height of fever should not be taken as an indicator of the severity of the underlying pathology by itself. In children of less than 3 months of age, height of fever may be an indicator of severe bacterial infection [23].

In our study $10 \%$ of participants agreed that a sleeping febrile child should not be disturbed. There are studies which show that parents, physicians and nurses awaken sleeping febrile children who have no other symptoms for antipyretic administration [33,58,59]. According to some paediatricians, sleeping febrile child should not be awaken for any reason, including medication $[9,33]$.

More than half of participating physicians (66.3\%) agreed that paracetamol and ibuprofen are the only antipyretic drugs which should be used in children. Studies show that both drugs are more effective than placebo, and can be used confidently in children [60-63]. Evidence obtained from randomised controlled clinical trials show that paracetamol and ibuprofen are the only antipyretic drugs recommended for use in children [23].

Because of the risk of Reye's syndrome, use of acetylsalicylic acid in children is not recommended [23]. Most of the physicians who participated in the present study (91.3\%) reported that Acetylsalicylic acid should not be used in a febrile child, although this has been known for a long time, nearly $10 \%$ of physicians still disagreed. 
In this study $77.5 \%$ of physicians preferred oral administration to rectal administration. Some investigations show that oral acetaminophen is more effective than the rectal form [64], others found they had similar effects $[65,66]$ so the comparison of the antipyretic effects of rectal and oral acetaminophen has conflicting results. Use of rectal paracetamol is not recommended by the Italian Paediatric Society [23] because of the risk of overdose. It is difficult to achive precise dosage in rectal administration. It depends on the child's body weight rather than age [67].

There are conflicting results about fever management in the literature and this situation could affect the practices of physicians. In many articles alternative treatments of fever with paracetamol and ibuprofen are recommended [68-72] and alternating acetaminophen and ibuprofen in febrile children appears to be a common practice among physicians [70]. But according to a guideline about management of fever in children; combined or alternating the usage of ibuprofen and paracetamol is not recommended [23]. There is no evidence available that alternating therapy results in improvement in other clinical outcomes and there is also no evidence regarding the safety of this practice [73-75]. In the present study a great majority of physicians $(91.3 \%)$ stated that they advised parents to alternate the use of ibuprofen and paracetamol.

Preventive usage of antipyretic before vaccine application is a common implementation in primary health care in Turkey despite the absence of evidence. Most of the physicians (81.3\%) in our study reported that antipyretic usage should be recommended to prevent fever and local reaction associated with childhood vaccination. According to evidence obtained from well-designed randomised clinical trials, use of paracetamol or ibuprofen is not recommended to reduce fever and local reactions associated with vaccination $[76,77]$.

According to the present study, $71.3 \%$ of physicians reported that teething is a reason for fever. In a prospective study which was designed to clarify symptoms associated with teething, the most common symptoms were biting, drooling, gum-rubbing and sucking. Generalised irritability and a mild fever might also occur during the teething period [78]. In an another prospective study the variation in temperature remained within the normal range during the teething period [79].

\section{Conclusions}

Our data suggests that implementation of educational programs and using guidelines regarding the proper management of the febrile child are needed. There were misconceptions about management and complications of fever. Conflicting results about fever in the literature also confirm these misconceptions.
Although there are guidelines for many diseases in primary care, there is no national guidance on the management of fever in Turkey. Management varies across Turkey and also among physicians. As a result, there is a perceived need to improve the recognition, assessment, and management of fever with underlying illnesses in children.

\section{Competing interest}

The authors declare that they have no competing interests.

\section{Authors' contributions}

FD, chose the subject, was responsible for the planning and conducting of the study, collected the data, analyzed data and was primarily responsible for the writing of the manuscript. OS, collected the data and was responsible for the planning of the study. All authors read and approved the final manuscript.

\section{Author details}

'Department of Public Health, Acıbadem University School of Medicine, Gülsuyu Mah. Fevzi Çakmak Cad. Divan Sok. No: 1, Maltepe/ISTANBUL 34848, Turkey. ${ }^{2}$ Department of Communicable Diseases, The Ministery of Health of Turkey Local Health Authority, Yayla Mah. Ömer Karahasan Sok. No:6,

Zonguldak 67500, Turkey.

Received: 19 April 2012 Accepted: 28 August 2012

Published: 5 September 2012

\section{References}

1. National Institute for Health and Clinical Excellence: Feverish illness in children-assessment and initial management in children younger than 5 years; 2007. NICE clinical guideline No 47.

2. McCarthy PL: Fever. Pediatr Rev 1998, 19(12):401-407.

3. Hull D: Fever - the fire of life. Arch Dis Child 1989, 64:1741-1747.

4. Kluger MJ: Fever revisited. Pediatrics 1992, 90:846-850.

5. Vanderschueren S, Knockaert D, Adriaenssens T, Demey W, Durnez A, Blockmans D, Bobbaers H: From prolonged febrile illness to fever of unknown origin: the challenge continues. Arch Intern Med 2003, 163(9):1033-1041.

6. Casteels-van Daele M: Management of childhood fever. Lancet 1991, 338:1408.

7. Schmitt BD: Fever phobia, misconceptions of parents about fever. AJDC 1980, 134(2):176-181.

8. May A, Baucher H: Fever phobia: the pediatrician contribution. Pediatrics 1992, 90(6):851-854.

9. Al-Eissa YA, Al-Zaben AA, Al-Wakeel AS, Al-Alola SA, Al-Shaalan MA, Al-Amir AA, Al-Shamsan LA: Physician's perceptions of fever in children facts and myths. Saudi Med J 2001, 22(2):124-128.

10. Crocetti M, Moghbeli N, Serwint J: Fever phobia revisited: heave parental misconceptions about fever changes in 20 years? Pediatrics 2001, 107:1241-1246.

11. Walsh A, Edwards $H$, Fraser J: Influences on parents' fever management: beliefs, experiences and information sources. J Clin Nurs 2007, 16(12):2331-2340.

12. Betz MG, Grunfeld AF: 'Fever phobia' in the emergency department: a survey of children's caregivers. Eur J Emerg Med 2006, 13(3):129-133.

13. Richardson M, Lakhanpaul M: Feverish illness in children under 5 years. Arch Dis Child Educ Pract Ed 2008, 93:26-29.

14. Seow VK, Lin AC, Lin IY, Chen CC, Chen KC, Wang TL, Chong CF: Comparing different patterns for managing febrile children in the ED between emergency and paediatric physicians: impact on patient outcome. Am J Emerg Med 2007, 25(9):1004-1008.

15. Dlugosz CK, Chater RW, Engle JP: Appropriate use of nonprescription analgesics in paediatric patients. J Pediatr Health Care 2006, 20(5):316-325.

16. Ishimine $P$ : The evolving approach to the young child who has fever and no obvious source. Emerg Med Clin North Am 2007, 25(4):1087-1115.

17. Poirier MP, Davis PH, Gonzalez-Del Ray JA, Monroe KW: Pediatric emergency department nurses' perspectives on fever in children. Pediatr Emerg Care 2000, 16(1):9-12. 
18. Watts R, Robertson J, Thomas G: Nursing management of fever in children: a systematic review. Int J Nurs Pract 2003, 9(1):1-8.

19. Dodd SR, Lancaster GA, Craig JV, Smyth RL, Williamson PR: In a systematic review, infrared ear thermometry for fever diagnosis in children finds poor sensitivity. J Clin Epidemiol 2006, 59(4):354-357

20. Robinson JL, Seal RF, Spady DW, Joffres MR: Comparison of esophageal, rectal, axillary, bladder, tympanic, and ulmonary artery temperatures in children. J Pediatr 1998, 133(4):553-556.

21. Wells N, King J, Hedstrom C, Youngkins J: Does tympanic temperature measure up? MCN Am J Matern Child Nurs 1995, 20(2):95-100

22. El-Radhi AS, Barry W: Termometry in paediatric practice. Arch Dis Child 2006, 91(4):351-356.

23. Chiappini E, Principi $N$, Longhi $R$, Tovo P-A, Becherucci $P$, Bonsignori $F$, Esposito S, Festini F, Galli L, Luccehesi B, Mugelli A, Martino M: Management of fever in children: summary of italian paediatric society guidelines. Clin Ther 2009, 31(8):1826-1843.

24. Meremikwu M, Oyo-Ita A: Physical methods for treating fever in children Cochrane Database Syst Rev 2003, (2):CD004264.

25. Mahar AF, Allen SJ, Milligan P, Suthumnirund S, Chotpitayasunondh T, Sabchareon A, Coulter JBS: Tepid sponging to reduce temperature in febrile children in a tropical climate. Clin Pediatr (Phila) 1994, 33:227-231.

26. Sharber J: The efficacy of tepid sponge bathing to reduce fever in young children. Am J Emerg Med 1997, 15(2):188-192.

27. Hay AD, Costelloe C, Redmond NM, Montgomery AA, Fletcher M, Hollinghurst S, Peters TJ: Paracetamol plus ibuprofen for the treatment of fever in children (PITCH): randomised controlled trial. BMJ 2008, 337:2a1302. doi:10.1136/bmj.a1302. Erratum in: BMJ. 2009;339:b3295.

28. Nijman RG, Oostenbrink R, Dons EM, Bouwhuis CB, Moll HA: Parental fever attitude and management, influence of parental ethnicity and child's age. Pediatr Emerg Care 2010, 26(5):339-342.

29. Richardson M, Lakhanpaul M, Guideline Development Group and the technical team: Assessment and initial management of feverish illness in children younger than 5 years: summary of NICE guidance. BMJ 2007 334(7604):1163-1164.

30. Makoni M, Mukundan D: Fever. Curr Opinion Pediat 2010, 22:100-106.

31. Eichenwald HF: Fever and antipyresis. Bull World Health Organ 2003, 81(5):372-374

32. Habbick BF: Fever in children: should it be treated? Can Fam Physician 1988, 34:1161-1164

33. Sarrell M, Cohen HA, Kahan E: Physicians', nurses' and parents' attitudes to and knowledge about fever in early childhood. Patient Educ Couns 2002, 46(1):61-65.

34. Walsh AM, Edwards HE, Courtney MD, Wilson JE, Monoghan SJ: Pediatric nurses' knowledge, attitudes and factors influencing fever management. J Adv Nurs 2005, 49:453-464.

35. Sarrel M, Cohen H, Kahan E: Physicians', nurses' and parents' attitudes to and knowledge about fever in early childhood. Patient Educ Couns 2002, 46(1):61-65.

36. Zomorrodi A, William AM: Fever: parental concerns. Clin Ped Emerg Med 2008, 9:238-243

37. Alexander KC, Lane W, Robson M: Febrile seizures. J Pediatr Health Care 2007, 21:250-255.

38. Shinnar S, Glauser TA: Febrile seizures. J Child Neurol 2002, 17:44-52.

39. Verity CM, Greenwood R, Golding J: Long term intellectual and behavioral outcome of children with febrile convulsion. N Engl J Med 1998, 338:1723-1728.

40. Kolfen W, Pehel K, Konig S: Is long term outcome of children following febrile convulsion favorable? Dev Med Child Neurol 1998, 40(10):667-671.

41. Sillanpa M, Suominen S, Rautava P, Aromaa M: Academic and social success in adolescents with previous febrile seizures. Seizure 2011, 20:326-330.

42. Nelson $\mathrm{KB}$, Elleberg $\mathrm{JH}$ : Prognosis in children with febrile seizures. Pediatrics 1978, 61:720-727.

43. Al-Eissa YA, Al-Herbish AS, Al-Jarallah AA, Familusi JB: Antecedents and outcome of simple and complex febrile convulsions among Saudi children. Dev Med Child Neurol 1992, 34:1085-1090.

44. Chang YC, Guo NW, Wang ST, Huang CC, Tsai JJ: Working memory of school-aged children with a history of febrile convulsions: a population study. Neurology 2001, 57(1):37-42.

45. Ipp M, Jaffe D: Physicians' attitudes toward the diagnosis and management of fever in children 3 months to 2 years of age. Clin Pediatr 1993, 32(2):66-70.
46. Gururaj AK, Bener A, Al-Suweidi EK, Al-Tatari HM, Khadir AE: Predictors of febrile seizure: a matched case-control study. J Trop Pediatr 2001, 47(6):361-362

47. Van Zeijl JH, Mullaart RA, Galama J: The pathogenesis of febrile seizures: is there a role for specific infections? Rev Med Virol 2002, 12(2):93-106.

48. Virta M, Hurme M, Helminen M: Increased frequency of interleukin -1 beta (-511) allele 2 in febrile seizures. Pediatr Neurol 2002, 26(3):192-195

49. Berg AT: Are febrile seizures provoked by a rapid rise in temperature? Am J Dis Child 1993, 147(10):1101-1103.

50. Varma RR: Febrile seizures. Indian J Pediatr 2002, 69(8):697-700.

51. Champi C, Gaffney-Yocum P: Managing febrile seizures in children. Nurse Pract 1999, 24(10):28-45.

52. Sadleir LG, Scheffer IE: Febrile seizures. BMJ 2007, 334(7588):307-311.

53. Uhari $M$, Rantala $H$, Vainionpaa $L$, Kurttila R: Effect of acetaminophen and of low intermittent doses of diazepam on prevention of recurrences of febrile seizures. J Pediatr 1995, 126(6):991-995.

54. Alpert G, Hibbert E, Fleisher GR: Case-control study of hyperpyrexia in children. Pediatr Infect Dis J 1990, 9(3):161-163.

55. Trautner BW, Caviness AC, Gerlacher GR, Demmler G, Macias CG: Prospective evaluation of the risk of serious bacterial infection in children who present to the emergency department with hyperpyrexia (temperature of $106^{\circ} \mathrm{F}$ or higher). Pediatrics 2006, 118(1):34-40.

56. Stanley R, Pagon Z, Bachur R: Hyperpyrexia among infants younger than 3 months. Pediatr Emerg Care 2005, 21(5):291-294.

57. Press S: Association of hyperpyrexia with serious disease in children. Clin Pediatr (Phila) 1994, 33(1):19-25.

58. Matziou V, Brokalaki, Kyritsi H, Perdikaris P, Gymnopoulou, Merkouris A: What Greek mothers know about evaluation and treatment of fever in children: an interview study. Int J Nurs Stud 2008, 45:829-836.

59. Walsh AM, Edwards HE, Courtney MD, Wilson JE, Monaghan SJ: Pediatric fever management continuing education for clinical nurses. Nurse Educ Today 2006, 26(1):71-77.

60. Allmers H, Skudlik C, John SM: Acetaminophen use: a risk for asthma? Curr Allergy Asthma Rep 2009, 9(2):164-167.

61. Perrott DA, Piira T, Goodenough B, Champion GD: Efficacy and safety of acetaminophen vs ibuprofen for treating children's pain or fever: a meta-analysis. Arch Pediatr Adolesc Med 2004, 158(6):521-526.

62. Wilson JT, Brown RD, Kearns GL, Eichler VF, Johnson VA, Bertrand KM, Lowe BA: Single dose, placebo-controlled comparative study of ibuprofen and acetaminophen antipyresis in children. J Pediatr 1991, 119(5):803-811.

63. Van Esch A, Van Steensel-Moll HA, Steyerberg EW, Offringa M, Habbema JD, Derksen-Lubsen G: Antipyretic efficacy of ibuprofen and acetaminophen in children with febrile seizures. Arch Pediatr Adolesc Med 1995 149(6):632-637.

64. Leary PM, Walker KG, Van der Meulen W: Antipyretic effect of oral v. rectal paracetamol. S Afr Med J 1997, 87(12):1708.

65. Nabulsi M, Tamim H, Sabra R, Mahfoud Z, Malaeb S, Fakih H, Mikati M: Equal antipyretic effectivness of oral and rectal acetaminophen: a randomized controlled trial. BMC Pediatr 2005, 6:5-35.

66. Scolnik D, Kozer E, Jacobson S, Diamond S, Young NL: Comparison of oral versus normal and high-dose rectal acetaminophen in the treatment of febrile children. Pediatrics 2002, 110(3):553-556.

67. Bilenko N, Tessler H, Okbe R, Press J, Gorodischer R: Determinants of antipyretic misuse in children up to 5 years of age: a cross-sectional study. Clin Ther 2006, 28(5):783-793.

68. Pashapour N, Macooei AA, Golmohammadlou S: Alternating ibuprofen and acetaminophen in the treatment of febrile hospitalized children aged 924 months. Iran J Pediatr 2009, 19(2):164-168.

69. Diez DJ, Burgos RA, Garrido GJ, Ballester SA, Moreno CE: Use of alternating antipyretics in the treatment of fever in Spain. An Esp Pediatr 2001, 55(6):503-510.

70. Mayoral CE, Mariono RV, Rosenfeld W, Greensher J: Alternating antipyretics: is this an alternative? Pediatrics 2000, 105(5):1009-1012.

71. Paul IM, Sturgis SA, Yang C, Engle L, Watts H, Berlin CM: Efficacy of standard doses of ibuprofen alone, alternating, and combined with acetaminophen for the treatment of febrile children. Clin Ther 2010, 32(14):2433-2440

72. Goldman RD: Alternating ıbuprofen and acetaminophen may be more effective in the treatment of fever in children. J Pediatr 2006, 149(1):140-141. 
73. Sullivan EJ, Farrar CH: Fever and antipyretic use in children. Pediatrics 2011, 127(3):580-587.

74. Purssell E: Systematic review of studies comparing combined treatment with paracetamol and ibuprofen, with either drug alone. Arch Dis Child 2011, 96:1175-79.

75. Carson MS: Alternating acetaminophen and ıbuprofen in the febrile child: examination of the evidence regarding efficacy and safety. Pediatr Nurs 2003, 29(5):379-382.

76. Kelley MT, Walson PD, Edge JH, Cox S, Mortensen ME: Pharmocokinetics and pharmacodynamics of ibuprofen isomers and acetaminophen in febrile children. Clin Pharmacol Ther 1992, 52(2):181-189.

77. Jackson LA, Dunstan M, Starkovich P, Dunn J, Yu O, Nelson JC, Rees T, Zavitskovsky A: Prophylaxis with acetaminophen or ibuprofen for prevention of local reactions to the fifth diphtheria-tetanus toxoidsacellular pertussis vaccination: a randomized, controlled trial. Pediatrics 2006, 117(3):620-625.

78. Ramos-Jorge J, Pordeus IA, Ramos-Jorge ML, Paiva SM: Prospective longitudinal study of signs and symptoms associated with primary tooth eruption. Pediatrics 2011, 128(3):471.

79. Macknin ML, Piedmonte M, Jacobs J, Skibinski C: Symptoms associated with infant teething: a prospective study. Pediatrics 2000, 105(4):747-752.

doi:10.1186/1824-7288-38-40

Cite this article as: Demir and Sekreter: Knowledge, attitudes and

misconceptions of primary care physicians regarding fever in children: a cross sectional study. Italian Journal of Pediatrics 2012 38:40.

\section{Submit your next manuscript to BioMed Central and take full advantage of:}

- Convenient online submission

- Thorough peer review

- No space constraints or color figure charges

- Immediate publication on acceptance

- Inclusion in PubMed, CAS, Scopus and Google Scholar

- Research which is freely available for redistribution 